\title{
Saving the zone of stasis in burns with melatonin: an experimental study in rats
}

\author{
Muhammed Kayapınar, M.D., ${ }^{1}$ Nevra Seyhan, M.D., ${ }^{1}$ \\ Mustafa Cihad Avunduk, M.D., ${ }^{2}$ Nedim Savacı, M.D. ${ }^{1}$ \\ 1Department of Plastic Surgery, Necmettin Erbakan University Faculty of Medicine, Konya \\ 2Department of Pathology, Necmettin Erbakan University Faculty of Medicine, Konya
}

\begin{abstract}
BACKGROUND: Studies aimed at recovering the zone of stasis are one of the major issues of experimental burn studies. Many drugs including antithrombotics, anticoagulants, anti-inflammatories have been investigated experimentally for saving the zone of stasis. In this study, the effect of the systemic melatonin on the zone of stasis was evaluated.

METHODS: Twenty Wistar Albino rats were used in the study. Rats were assigned to two groups $(\mathrm{n}=10)$. The metal comb $1 \times 2 \mathrm{~cm}$ in size was immersed in boiling water and held for 20 seconds on the back of the rats to create burn wounds.No treatment was given to the control group. Melatonin was given at a dose of $10 \mathrm{mg} / \mathrm{kg} / \mathrm{d}$ by intraperitoneal injection in the treatment group for 7 days. Daily digital photographs of both groups were obtained. Total necrotic burn areas and the zone of stasis were assessed with Auto CAD and Visual Analyzing computer programs. At the end of one week, rats were sacrificed and skin biopsies were taken for histological examination. Edema, congestion, inflammatory infiltration, vascular proliferation and fibrosis were the parameters evaluated. Data were evaluated statistically by Chi-square test and Student-t test.
\end{abstract}

RESULTS: When histopatologic data and the measured values for total necrotic areas and zone of stasis of the experimental group werecompared to control group, the results were statistically significant $(p<0.05)$.

CONCLUSION: According to the results of this study, melatonin is efficient in saving the zone of stasis in burns.

Key words: Burn model; melatonin; zone of stasis.

\section{INTRODUCTION}

Salvaging the zone of stasis is of clinical importance for burn specialists because saving this zone prevents the potential increase in the depth and width of the burned area, thereby decreasing mortality and morbidity. ${ }^{[1]}$ Based on the severity of destruction and blood flow alterations, three distinct zones of tissue injury can be distinguished. Jackson described these three zones in 1947..2] The zone of coagulation is the central zone, which is directly and irreversibly affected by the burn. Coagulation necrosis is the characteristic sign of this area.

Address for correspondence: Muhammed Kayapınar, M.D.
Necmettin Erbakan Üniversitesi Tıp Fakültesi, Plastik Cerrahi
Anabilim Dalı, Konya, Turkey
$\begin{array}{ll}\text { Tel: +90 } 332 \text { - } 2236000 & \text { E-mail: drmuhammetkayapinar@gmail.com } \\ & \\ \text { Qucik Response Code } & \text { Ulus Travma Acil Cerrahi Derg } \\ & \text { 20I5;2I(6):419-424 } \\ & \text { doi: I0.5505/tjtes.20I5.53059 } \\ & \text { Copyright 20I5 }\end{array}$

The area encircling the zone of coagulation is the zone of stasis, which is affected indirectly by the trauma. ${ }^{[4]}$

The outermost layer is the zone of hyperemia with increased blood flow, representing an inflammatory response to the tissue injury. It always stays viable. Investigations on the pathobiology of the zone of stasis revealed that irreversible tissue necrosis ensues with progression of hypoxia and ischemia in I-48 hours, resulting in total loss of this intermediate zone. ${ }^{[4]}$ In this zone, petechial hemorrhage, vascular thrombosis, increased vascular permeability and local edema are seen. Local edema increases the severity of hypoxia. Diminished circulation in this region results in progressive ischemia. Maintaining adequate blood flow and vessel patency can save viable tissues and dermis of this zone of stasis. [5] Both hypercoagulability and systemic activation of white blood cells are reported as underlying reasons of progressive tissue injury in this zone. Relying on experimental studies, treatment modalities, such as increasing tissue tolerance to ischemia, enhancement of perfusion and inhibition of inflammatory response, have been proposed to enable salvage of this zone. The use of antithrombotic, anticoagulant, anti-in- 
flammatory and antioxidant medication has all been studied. [4] The hormone melatonin ( $\mathrm{N}$-acetyl-5methoxy-tryptamine) is produced by the pineal gland. Melatonin is known to exhibit free radical scavenging ability and reduces neutrophil accumulation. ${ }^{[6]}$ The scavenging ability of melatonin is more effective than other intracellular antioxidants. ${ }^{[7]}$ The aim of this study was to test the effects of melatonin, the chief secretory product of pineal gland and a highly effective antioxidant, on saving the zone of stasis in rats.

\section{MATERIALS AND METHODS}

\section{Animals and the Burn Model}

In this experiment, twenty Wistar albino rats weighing 250 to $275 \mathrm{~g}$ were used. The animals were caged individually at room temperature with a $12 \mathrm{~h}$ light/dark cycle and had free access to water and standard laboratory food for rats. General anesthesia was induced with intramuscular ketamine (10\%) 80 $\mathrm{mg} / \mathrm{kg}$ and xylazine $(2 \%) 10 \mathrm{mg} / \mathrm{kg}$. The dorsal skins of the rats were shaved. A metal comb $1 \times 2 \mathrm{~cm}$ in size was immersed in boiling water for $5 \mathrm{~min}$, until thermal equilibrium was achieved between the comb and the water. The heated comb was placed on the back of the rat $0.5 \mathrm{~cm}$ lateral and parallel to midline and held for $20 \mathrm{sec}$ without pressure (Fig. I). Four burn areas $(1 \times 2 \mathrm{~cm})$ and three interspaces were created on one side. The same burn model was made on the other side of the rat's back again 15 min later (Fig. 2). Twenty rats were randomly separated to control (Group I) and experi-

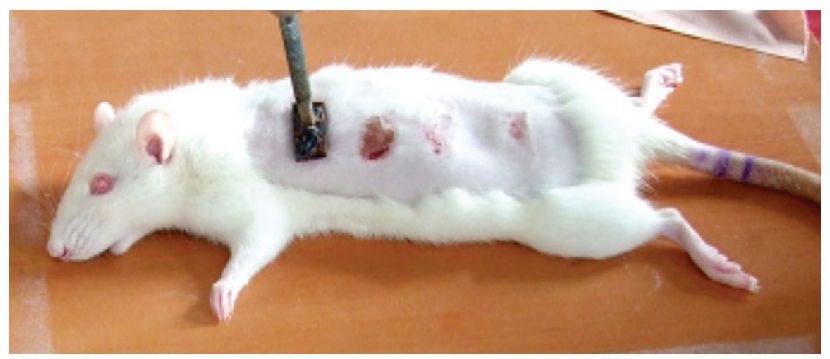

Figure 1. Application of metal comb on the back of the rat for creating burn wound.

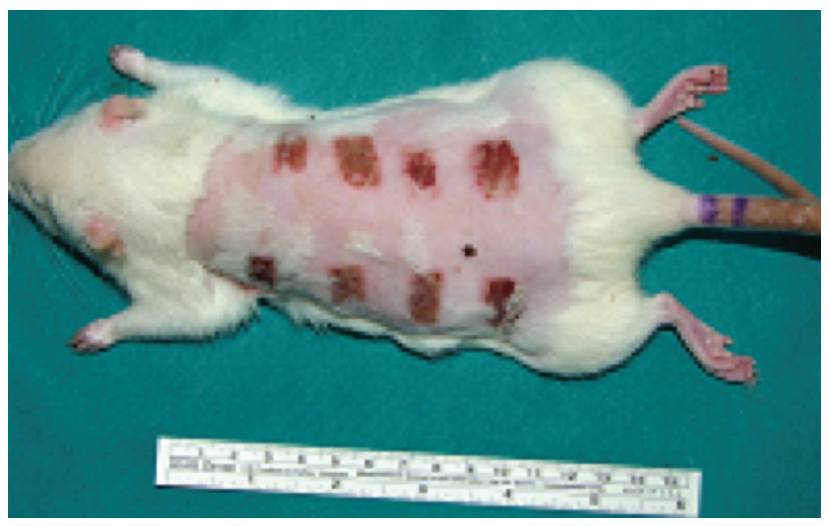

Figure 2. Full thickness skin burns were created $0.5 \mathrm{~cm}$ lateral and paralel to midline.
Table I. The values of total necrotic burn area in $\mathrm{mm}^{2}$ measured by photoanalysis method

\begin{tabular}{lcc}
\hline & Group I & Group 2 \\
\hline 1 & 132.78 & 52.42 \\
2 & 124.34 & 75.14 \\
3 & 141.08 & 92.10 \\
4 & 112.36 & 67.2 \\
5 & 107.80 & 70.10 \\
6 & 125.47 & 62.12 \\
7 & 130.18 & 76.10 \\
8 & 99.8 & 63.21 \\
9 & 102.7 & 64.37 \\
10 & 107.89 & 42.22 \\
\hline
\end{tabular}

mental (Group 2) groups. Each group was consisted of ten rats. Thirty minutes after burn injury, the treatment group was treated with melatonin. The control group received no treatment. Daily intraperitoneal melatonin injection $10 \mathrm{mg} / \mathrm{kg}$ continued for 7 days.

\section{Photoanalysis}

Daily photographs of the burned areas in both groups were taken under diethylether anesthesia. The initial surface of the burned area was assigned as $200 \mathrm{~mm}^{2}$. Auto CAD computer programme was used to calculate the burned areas in the photographs. By placing milimetric ruler in each photograph, calibration was done for the calculation of the burned area in square millimeter (Fig. 3). Necrotic areas were calculated and the obtained values recorded (Table I). The total necrotic areas between the two groups were compared.

\section{Histological Analysis}

The rats were sacrificed 7 days after burn injury. Skin biopsies were taken from full thickness burn areas. Samples were fixed in neutral buffered formalin and embedded in paraffin me-

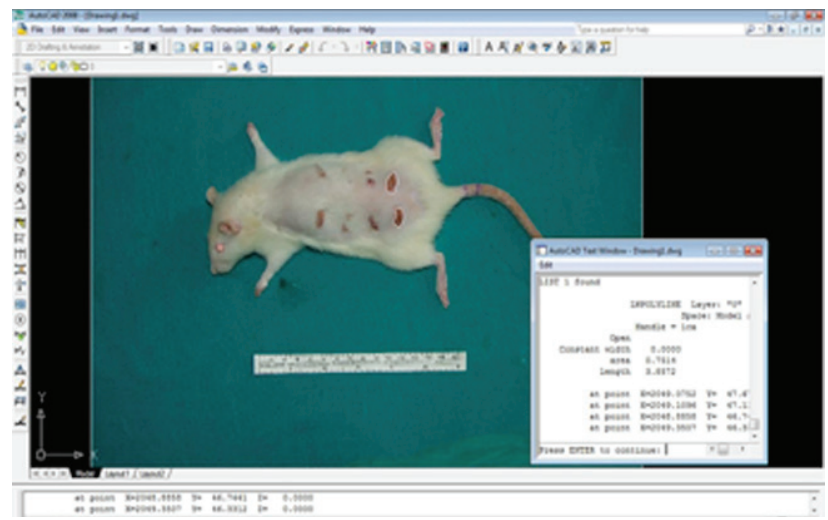

Figure 3. Calculation of the necrotic areas in burn wounds by AutoCAD computer program. 
Table 2. The values of total necrotic burn area in $\mathrm{mm}^{2}$ measured by Visual Analyzing programme

\begin{tabular}{lcc}
\hline & Group I & Group 2 \\
\hline 1 & 11.2 & 6.8 \\
2 & 13.7 & 8.2 \\
3 & 9.6 & 5.4 \\
4 & 8.4 & 4.9 \\
5 & 10.7 & 6.8 \\
6 & 8.8 & 5.5 \\
7 & 6.5 & 4.3 \\
8 & 12.6 & 4.2 \\
9 & 14.4 & 4.6 \\
10 & 8.9 & 4.1 \\
\hline
\end{tabular}

dia. Micron sections were deparafinnized and processed for hemotoksilin eosin staining. Histological preparations were investigated under Nikon Eclipse E400 light microscope. Digital images of the zone of stasis were taken by Nikon Coolpix 5000 digital camera connected to Nikon SMZ I500 steroscopic light microscope. All digital images were analyzed by Visual Analyzing programme (Clemex Vision Lite 3.5, Canada). The zone of stasis was marked as two points, and Visual Analyzing programme automatically measured the distance between these two points (Figs. $4 a, b)$ and the obtained values were recorded (Table 2 ) Histological parameters evaluat-
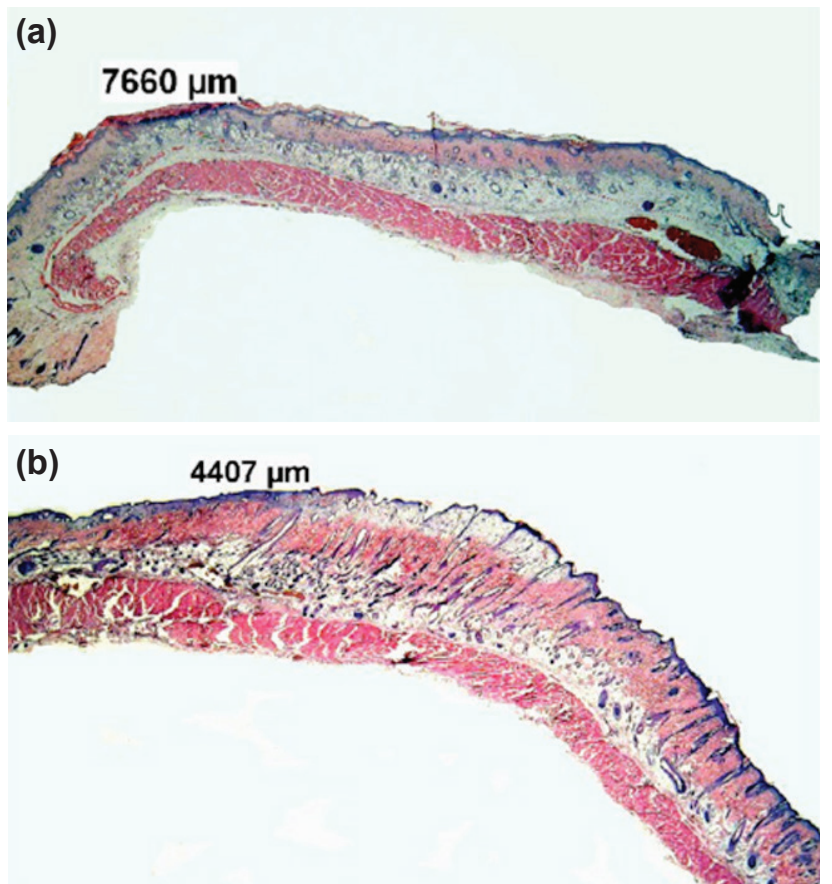

Figure 4. (a) Measurement of the zone of stasis by Visual Analyzing computer program in the control group. (b) Measurement of the zone of stasis by Visual Analyzing computer program in the experimental group. ed included edema, congestion, inflammatory infiltration, vascular proliferation and fibrosis. Each parameter was graded based on a scale from 0 to 3 as 0: none, I: mild, 2: moderate and 3: significant (Figs. 5a-d). Evaluations of histology were made by a pathologist blinded to the groups.

\section{Statistical Analysis}

In order to evaluate the differences in datas of edema, congestion, inflammatory infiltration, vascular proliferation and fibrosis, Chi square test was used. Student-T test was used to assess the numeric data for necrotic burn and zone of stasis areas. Significance was assigned at $p<0.05$.

\section{RESULTS}

No deaths occurred during this study. At the end of 7 days gross observation revealed that in the experimental group, most of the interspace areas appeared to be alive while in the control group; the interspace areas were necrotic in appearance. The mean percentage of the calculated necrotic area

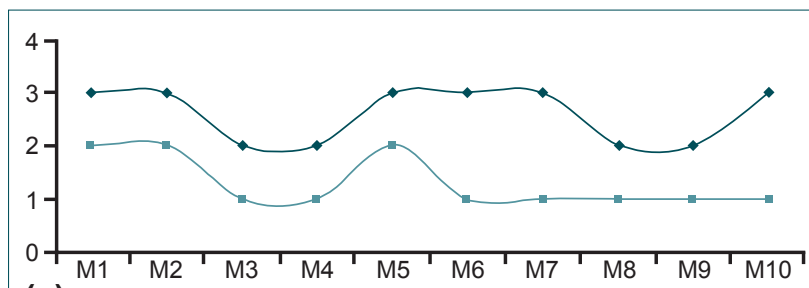

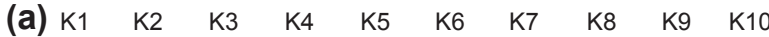
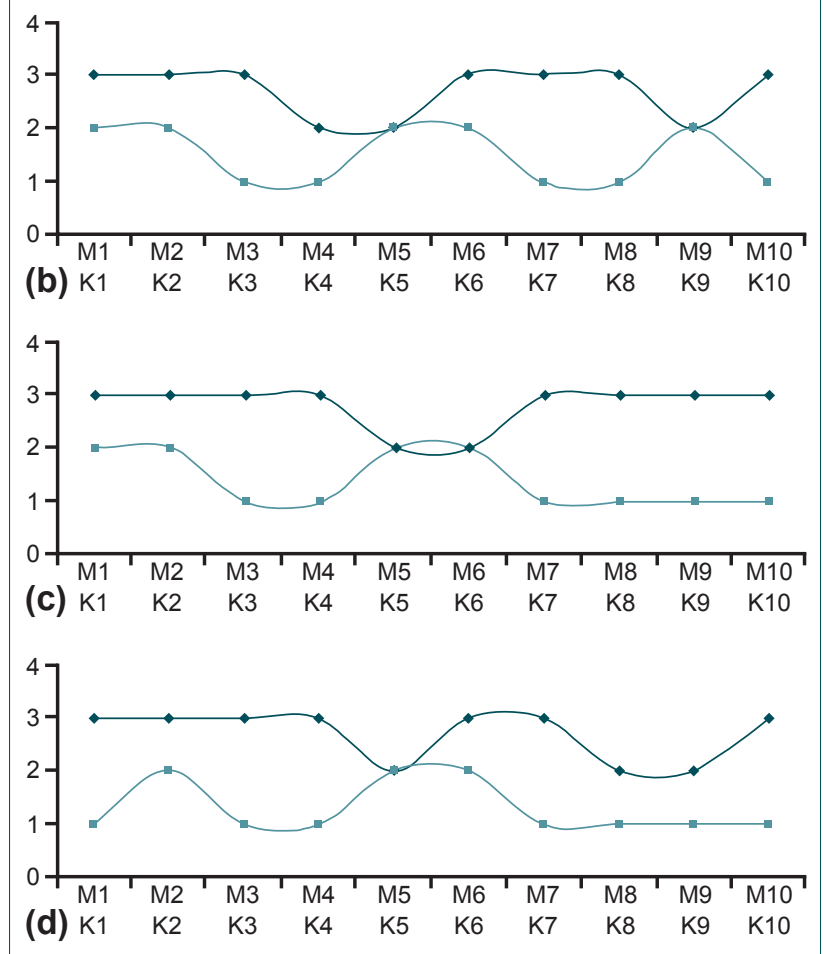

Figure 5. Schematic presentation of the grading scale of each histologic parameter for both control and experimental groups are shown. (a) Fibrosis, (b) vascular proliferation, (c) congestion, (d) inflammatory infiltration. 


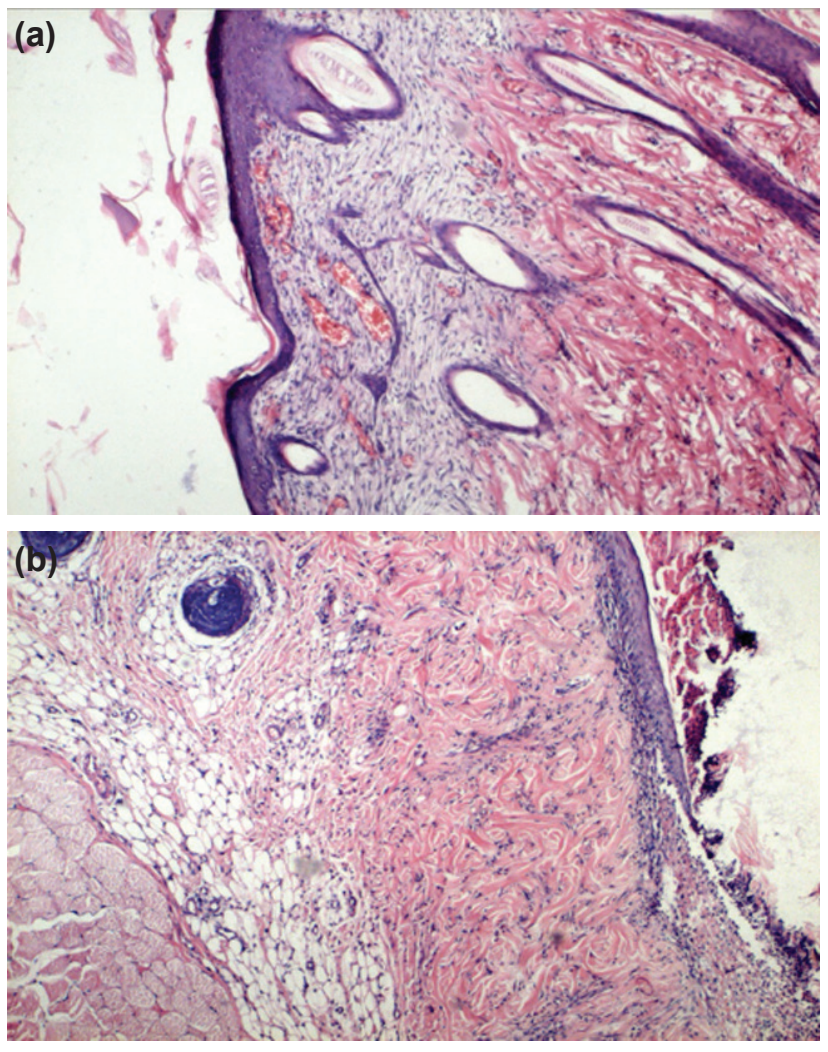

Figure 6. (a) In the control group; under the epithelium vascular proliferation, fibrosis and inflammatory infiltration are more prominent. (b) In the experimental group; less vascular proliferation, fibrosis and inflammatory infiltration are observed under the epithelium.

by Auto CAD programme and measurement of the distance of the stasis zone by Visual Analyzing programme in the control group was higher than that of the experimental group. Comparison of the data obtained by AUTO CAD program showed statistical significance $(p<0.05)$. All the data obtained from the investigation of histopathological parameters including edema, congestion, inflammatory infiltration, vascular proliferation and fibrosis was found to be higher in the control group when compared with the experimental group (Figs. 6a, b). The difference between the groups were all statistically significant $(p<0.05)$.

\section{DISCUSSION}

As long as proper interventions are undertaken during the first 72 hours following thermal injury, tissue damage in the zone of stasis may be reversible. The comb burn model first described by Regas and Erlich has been found to be ideal for research on the zone of stasis ${ }^{[8]}$ and has been used in many experimental models until today. Inflammation, ischemia and oxygen free radical formation affect the viability of the zone of stasis. Relying on experimental studies, treatment modalities, such as increasing tissue tolerance to ischemia, enhancement of perfusion and inhibition of inflammatory response, have been proposed to enable salvage of the zone of stasis.
Ischemia reperfusion stimulates inflammatory cells to generate reactive oxygen species (ROS) in many tissues especially after burns. Free oxygen radicals and peroxidases increase following cutaneous burn. Production of oxygen derived free radicals result in the disruption of plasma membranes. The major targets of ROS are long chain-polyunsaturated fatty acids of cellular phospholipids. Antioxidants prevent potential cellular damage resulting from ROS. Melatonin is a safe and non-toxic molecule, penetratingcells to scavenge free radicals. ${ }^{[9]}$ It is highly lipophilic, and it passes easily through biological membranes. ${ }^{[10]}$ This is an advantage for melatonin over some other antioxidants, which penetrate cells more slowly. It also acts synergistically with antioxidant agents such as vitamins $\mathrm{C}, \mathrm{E}$ and glutathione. ${ }^{\left[{ }^{[1]}\right]}$

Melatonin activates glutathione peroxidase (GSH-Px) and reduces lipid peroxidation. ${ }^{[12,13]}$ It also stimulates superoxide dismutase and inhibits human platelet aggregation and thromboxane production. ${ }^{[14]}$ Urata et al. have found that the rate limiting enzyme in GSH synthesis, gama-glutamylcysteine synthetase, is increased after the administration of melatonin to rats. ${ }^{[15]}$

Burn injury causes systemic activation of leucocytes and accumulation of white cells in microcirculation. ${ }^{[16]}$ Neutrophil recruitment and adherence to the endothelium following burn injury decreases the lumen diameter ${ }^{[17]}$ and results in microvascular compromise. Bertuglia et al. have reported that treatment with melatonin completely inhibits microvascular edema formation, reduces the number of leukocytes sticking to venules, and preserves microvascular perfusion. ${ }^{[18]}$ It has been shown that antibodies which block adhesion of neutrophil to endothelial cell following $30 \mathrm{~min}$ following burn improve blood flow in the zone of stasis. [19-21] Melatonin blocks the synthesis of adhesion molecules, which increase leukocyte infiltration into the damaged tissue. Melatonin increases, but gluthatione decreases $\mathrm{NO}$ levels. Although $\mathrm{NO}$ is an essential molecule, it is also a free radical and its production is not always beneficial. Excessive NO production has harmful effects in microcirculation. When the production of $\mathrm{NO}$ increases, its production must be controlled. The reaction of $\mathrm{NO}$ and superoxide anion generates peroxynitrite (ONOO-). ONOO; which is a highly reactive molecule, reacts with cellular component (e.g. membrane lipids and proteins), disturbing their function and consequently cellular hemostasis. ${ }^{[22]}$ Melatonin has an inhibitory effect on NOS activity. Tissue NO level was reduced after melatonin treatment in a rat skin flap ischemia-reperfusion model. ${ }^{[23]}$ In this experiment, melatonin significantly decreased malondialdehyde (MDA) levels, which is an end product of lipid peroxidation and elevated the GSH content. MAD is generated as a result of toxic effects of active oxygen radicals. It destroys unsaturated fatty acids in the cell membranes. In addition, melatonin inhibits the production of tumor necrosis factor. ${ }^{[24]}$ TNF- $\alpha$ is known to induce neutrophil and endothelial cell activation. ${ }^{[25]} \mathrm{Ce}-$ 
rium nitrate ${ }^{[26]}$ and $\mathrm{N}$-acetylcysteine ${ }^{[27]}$ was found to be effective in saving the zone of stasis by decreasing the level of TNF production.

An ideal pharmacological agent for saving the zone of stasis should have the following features: safety, clinical availability, and easy administration. Melatonin fulfills all of these criteria. Anti-thrombotic agents have serious side effects that restrict their clinical use; whereas, melatonin has a very little side effect potential.

Melatonin induced microvascular protection is the result of its scavenging effect on free radicals. In the present study, use of melatonin due to its antioxidant effect showed favorable results in saving the zone of stasis. In conclusion, systemic usage of melatonin may be considered as an effective method to prevent the cells in the zone of stasis to go under necrosis and possible extension of burn area.

\section{Conflict of interest: None declared.}

\section{REFERENCES}

1. Uygur F, Evinc R, Urhan M, Celikoz B, Haholu A. Salvaging the zone of stasis by simvastatin: an experimental study in rats. J Burn Care Res 2009;30:872-9. CrossRef

2. Jackson Dm. The diagnosis of the depth of burning. [Article in Undetermined Language] Br J Surg 1953;40:588-96. CrossRef

3. Zor F, Ozturk S, Deveci M, Karacalioglu O, Sengezer M. Saving the zone of stasis: is glutathione effective? Burns 2005;31:972-6. CrossRef

4. Nisanci M, Eski M, Sahin I, Ilgan S, Isik S. Saving the zone of stasis in burns with activated protein C: an experimental study in rats. Burns 2010;36:397-402. CrossRef

5. Işik S, Sahin U, Ilgan S, Güler M, Günalp B, Selmanpakoğlu N. Saving the zone of stasis in burns with recombinant tissue-type plasminogen activator ( $\mathrm{r}-\mathrm{tPA}$ ): an experimental study in rats. Burns 1998;24:217-23.

6. Reiter RJ, Melchiorri D, Sewerynek E, Poeggeler B, Barlow-Walden L, Chuang J, et al. A review of the evidence supporting melatonin's role as an antioxidant. J Pineal Res 1995;18:1-11. CrossRef

7. Tan DX Chen LD, Poeggeler B. Melatonin: A potent, endogenous hydroxyl radical scavenge. Endocr J 1993; 1:57-60.

8. Regas FC, Ehrlich HP. Elucidating the vascular response to burns with a new rat model. J Trauma 1992;32:557-63. CrossRef

9. Wang WZ, Fang XH, Stephenson LL, Baynosa RC, Khiabani KT, Zamboni WA. Microcirculatory effects of melatonin in rat skeletal muscle after prolonged ischemia. J Pineal Res 2005;39:57-65. CrossRef

10. Vaughan GM, Reiter RJ. Pineal dependence of the Syrian hamster's nocturnal serum melatonin surge. J Pineal Res 1986;3:9-14. CrossRef

11. Gitto E, Tan DX, Reiter RJ, Karbownik M, Manchester LC, Cuzzocrea S, et al. Individual and synergistic antioxidative actions of melatonin: studies with vitamin $\mathrm{E}$, vitamin $\mathrm{C}$, glutathione and desferrioxamine (desferoxamine) in rat liver homogenates. J Pharm Pharmacol 2001;53:1393-401.

12. Reiter RJ, Guerrero JM, Garcia JJ, Acuña-Castroviejo D. Reactive oxygen intermediates, molecular damage, and aging. Relation to melatonin. Ann N Y Acad Sci 1998;854:410-24. CrossRef

13. Reiter RJ, Tan DX, Osuna C, Gitto E. Actions of melatonin in the reduction of oxidative stress. A review. J Biomed Sci 2000;7:444-58. CrossRef

14. Del Zar MM, Martinuzzo M, Falcón C, Cardinali DP, Carreras LO, Vacas MI. Inhibition of human platelet aggregation and thromboxane-B2 production by melatonin: evidence for a diurnal variation. J Clin Endocrinol Metab 1990;70:246-51. CrossRef

15. Urata Y, Honma S, Goto S, Todoroki S, Iida T, Cho S, et al. Melatonin induces gamma-glutamylcysteine synthetase mediated by activator protein-1 in human vascular endothelial cells. Free Radic Biol Med 1999;27:838-47. CrossRef

16. Eski M, Deveci M, Celiköz B, Nisanci M, Türegün M. Treatment with cerium nitrate bathing modulate systemic leukocyte activation following burn injury: an experimental study in rat cremaster muscle flap. Burns 2001;27:739-46. CrossRef

17. Boykin JV, Eriksson E, Pittman RN. In vivo microcirculation of a scald burn and the progression of postburn dermal ischemia. Plast Reconstr Surg 1980;66:191-8. CrossRef

18. Bertuglia S, Marchiafava PL, Colantuoni A. Melatonin prevents ischemia reperfusion injury in hamster cheek pouch microcirculation. Cardiovasc Res 1996;31:947-52. CrossRef

19. Baskaran H, Toner M, Yarmush ML, Berthiaume F. Poloxamer-188 improves capillary blood flow and tissue viability in a cutaneous burn wound. J Surg Res 2001;101:56-61. CrossRef

20. Choi M, Rabb H, Arnaout MA, Ehrlich HP. Preventing the infiltration of leukocytes by monoclonal antibody blocks the development of progressive ischemia in rat burns. Plast Reconstr Surg 1995;96:1177-87.

21. Bucky LP, Vedder NB, Hong HZ, Ehrlich HP, Winn RK, Harlan JM, et al. Reduction of burn injury by inhibiting CD18-mediated leukocyte adherence in rabbits. Plast Reconstr Surg 1994;93:1473-80. CrossRef

22. Radi R, Peluffo G, Alvarez MN, Naviliat M, Cayota A. Unraveling peroxynitrite formation in biological systems. Free Radic Biol Med 2001;30:463-88. CrossRef

23. Gurlek A, Aydogan H, Parlakpinar H, Bay-Karabulut A, Celik M, Sezgin $\mathrm{N}$, et al. Protective effect of melatonin on random pattern skin flap necrosis in pinealectomized rat. J Pineal Res 2004;36:58-63. CrossRef

24. Sacco S, Aquilini L, Ghezzi P, Pinza M, Guglielmotti A. Mechanism of the inhibitory effect of melatonin on tumor necrosis factor production in vivo and in vitro. Eur J Pharmacol 1998;343:249-55. CrossRef

25. Deveci M, Eski M, Sengezer M, Kisa U. Effects of cerium nitrate bathing and prompt burn wound excision on IL-6 and TNF-alpha levels in burned rats. Burns 2000;26:41-5. CrossRef

26. Eski M, Ozer F, Firat C, Alhan D, Arslan N, Senturk T, et al. Cerium nitrate treatment prevents progressive tissue necrosis in the zone of stasis following burn. Burns 2012;38:283-9. CrossRef

27. Deniz M, Borman H, Seyhan T, Haberal M. An effective antioxidant drug on prevention of the necrosis of zone of stasis: $\mathrm{N}$-acetylcysteine. Burns 2013;39:320-5. CrossRef 
DENEYSEL ÇALIŞMA - ÖZET

\section{Yanık staz zonunun melatonin kullanımıyla kurtarılması: Sıçanlarda deneysel çalışma}

Dr. Muhammed Kayapınar, ${ }^{1}$ Dr. Nevra Seyhan, ${ }^{1}$ Dr. Mustafa Cihad Avunduk, ${ }^{2}$ Dr. Nedim Savacı

${ }^{1}$ Necmettin Erbakan Üniversitesi Tıp Fakültesi, Plastik Cerrahi Anabilim Dalı, Konya

${ }^{2}$ Necmettin Erbakan Üniversitesi Tıp Fakültesi, Patoloji Anabilim Dalı, Konya

AMAÇ: Staz zonunun kurtarımasını amaçlayan çalışmalar deneysel yanık çalışmalarının önemli bir bölümünü oluşturmaktadır. Staz zonunun kurtarılmasında deneysel olarak antitrombotik, antienflamatuvar, antikoagülan gibi birçok ilaç araştırılmıştır. Bu çalısmanın amacı sistemik melatoninin staz zonuna etkisini değerlendirmektir.

GEREÇ VE YÖNTEM: Çalışmada 20 adet erişkin Wistar Albino sıçan kullanıldı. Randomize seçilen sıçanlar iki gruba ayrıldı $(n=10)$. Sıçanların sırtları tıraşlandıktan sonra IX2 cm ebadında kaynar suda ısıtılmış metal plak 20 sn bekletilerek yanık oluşturuldu. Kontrol grubuna tedavi verilmedi. Tedavi grubuna yedi gün süreyle $10 \mathrm{mg} / \mathrm{kg} /$ gün dozunda intraperitoneal melatonin enjeksiyonu yapıldı. Her iki grubun günlük dijital fotoğrafları çekildi. Total nekrotik yanık alanları ve staz zonu Auto CAD ve görüntü analizi programlarıyla değerlendirildi. Bir hafta sonunda sıçanlar sakrifiye edilerek histolojik inceleme için cilt biyopsisi alındı. Ödem, konjesyon, enflamatuvar infiltrasyon, vasküler proliferasyon ve fibrozis değerlendirilen parametrelerdi. Elde edilen veriler ki-kare ve student t-testleri ile değerlendirildi.

BULGULAR: Experimental gruba ait histopatolojik veriler ile total nekrotik yanık alanları ve staz zonu ölçümlerine ait sayısal veriler kontrol grubu ile karşılaştıııldı̆̆ında melatoninin staz zonuna etkinliğini kanıtlayacak şekilde istatistiksel olarak anlamlıydı $(p<0.05)$.

TARTIŞMA: Bu çalışmanın sonucuna göre yanıkta staz zonunun kurtarılmasında melatonin etkilidir.

Anahtar sözcükler: Melatonin; staz zonu; yanık.

Ulus Travma Acil Cerrahi Derg 2015;2I(6):419-424 doi: 10.5505/tjtes.2015.53059 